\title{
„Szaleństwo ciał” — pornografia współczesna a medykalizacja ciała. Implikacje historycznomedyczne*
}

DOI: 10.19195/2083-7763.8.8

[S]eks jest jedna z trzech najlepszych rzeczy na świecie, choć nie mam pojęcia, jakie sa dwie pozostałe

Helen Gurley Brown (1922-2012) ${ }^{1}$

Stwierdzenie "pornografia jest o seksie” wydaje się banalne i oczywiste. Nie jest tak jednakże do końca. Z perspektywy historycznej - w standardzie interpretacyjnym antropologii wiedzy nawiązującym do konwencjonalizmu historycznego $^{2}-$ dzisiejsze rozumienie tego zdania implikuje i ukazuje zmiany, jakie zaszły w seksualności oraz w stosunku do niej. Przedstawione poniżej rozważania odnoszą się szczególnie do „pornografii mainstreamowej”, którą definiuję jako skierowaną szczególnie do heteroseksualnego, męskiego odbiorcy, mającą charakter profesjonalny i produkowaną w jednym z tak zwanych krajów zachodnich. Choć nie musi być to regułą i może dotyczyć (w określonych wymiarach i aspektach) pornografii mniejszości seksualnych, pornografii produkowanej poza kulturą zachodnią oraz w warunkach nieprofesjonalnych (amatorskich, prywatnych) ${ }^{3}$.

Tezą niniejszego artykułu jest „somatyzacja” pornografii jako jej swoiste „przeorientowanie" funkcjonalne i jakościowe. W zasadzie od początku XX wieku do lat

* Publikacja zrealizowana w ramach działalności statutowej Muzeum Farmacji Uniwersytetu Medycznego im. Piastów Śląskich we Wrocławiu, program ST-961.

1 "[S]ex is one of the three best things there are, and I don't know what the other two are" H.G. Brown, I'm Wild Again: Snippets of My Life and a Few Brazen Thoughts, New York 2000, s. 52.

2 Por. m.in. B. Płonka-Syroka, Medycyna $w$ historii i kulturze. Studia $z$ antropologii wiedzy, Wrocław 2013, s. 23-188.

${ }^{3}$ Uwaga ta została zamieszczona by wskazać, że głównym źródłem poczynionych tu konstatacji nie jest pornografia mniejszości seksualnych, co jednak nie oznacza, że niektóre z tez czy konkluzji nie mogą być w pewnym zakresie zastosowane i do niej. 
siedemdziesiątych i osiemdziesiątych, czyli tak zwanego Złotego Wieku Porno (ang. Golden Age of Porn) mamy w narracji pornograficznej do czynienia z opowieścią o seksie w jego zróżnicowanych układach. Jest on zazwyczaj osadzony w kontekście sytuacyjnym (we wczesnych stag films nawet o charakterze groteskowym) oraz psychoemocjonalnym głównych bohaterów. Innymi słowy, akt seksualny „ma fabułę”, „ukontekstowienie”. Prowadzi do niego pewna droga.

Od lat dziewięćdziesiątych XX wieku, a szczególnie wraz z rozwojem Internetu na przełomie wieków, sytuacja ulega diametralnej zmianie (choć zmiany te są zakorzenione już w latach osiemdziesiątych - przy rozwoju technologii VHS i „prywatyzacji” pornografii). Kontekstem dla tych przeobrażeń są również zmiany społeczno-kulturowe, jakie zaszły w obrębie obyczajowości, modelu rodziny, relacji, emancypacji kobiet oraz w nauce. "Języczek uwagi” przesuwa się coraz bardziej w stronę ciała. Od tego momentu, można rzec, „pornografia jest o ciele" w kontekście jego aktywności seksualnej jako funkcjonalnej zdolności, lecz także zdeterminowanej biologicznie konieczności. Odchodzi się od warstwy i aspektów psychoemocjonalnych czy sytuacyjnych (fabularnych), w które obfitował jeszcze Złoty Wiek ${ }^{4}$. Głównym podmiotem i przedmiotem porno staje się ciało wyabstrahowane $\mathrm{z}$ kontekstu, $\mathrm{w}$ przeciwieństwie do bohatera wcześniejszej narracji pornograficznej, którego ciało było przedmiotem, a on sam podmiotem pornoretoryki. W najnowszej pornografii nie sposób natrafić (co nie oznacza, że zjawisko to nie występuje w ogóle, jednakże jest znacznie rzadsze aniżeli we wcześniejszych produkcjach) na wymiary psychoemocjonalne, które były właściwe wcześniejszym (szczególnie) bohaterkom pornoobrazów (sytuacja ta dotyczy szczególnie „pofragmentowanej” pornografii internetowej). W fabułę filmu wplecione były dylematy emocjonalne, psychiczne, estetyczne, a nawet moralno-etyczne. Sfera "nieokiełznanego" seksu o charakterze promiskuitycznym pojawiała się częstokroć w przestrzeni fantazji erotycznych głównej bohaterki/bohaterek (rzadziej bohatera), która musiała przejść pewną drogę, zanim dokonała ich urzeczywistnienia ${ }^{5}$. Te aspekty narracyjne pozostały w produkcjach typu soft, zaliczanych już jednakże do erotyki ${ }^{6}$, w tak zwanej pornografii feministycznej, określanej jako couples-oriented, czyli „zorientowana partnersko"7 oraz

${ }^{4}$ Por. m.in. L. Williams, Hard Core. Władza, przyjemność i „szaleństwo widzialności”, Gdańsk 2010, passim.

5 Konteksty emocjonalne, wątpliwości por. m.in. Behind the Green Door, reż. A. Mitchell, J. Mitchell, USA 1972; Debbie Does Dallas, reż. J. Buckley, USA 1978; Deep Throat (Głębokie gardło), reż. G. Damiano, USA 1972; Deep Throat Part II, reż. J.W. Sarno, USA 1974; Devil in Miss Jones (Diabeł w pannie Jones), reż. G. Damiano, USA 1973; Every Woman Has a Fantasy, reż. E. Brown, USA 1984; Three Daughters, reż. C. Royalle, USA 1986.

${ }^{6}$ Należy pamiętać, że granice pomiędzy tym, co określamy mianem erotyki i pornografii, są płynne i nieszczelne, a niekiedy mocno zrelatywizowane w zależności od podmiotu definiującego.

7 Por. L. Bragge, Girls on Top, 2004, http://www.theage.com.au/articles/2004/06/15/1087244912619.html (dostęp: 22.07.2015). 
produkcjach niepornograficznych, wykorzystujących jednakże konwencję pornoszyku ${ }^{8}$. Owe urzeczywistnienie fantazji erotycznych, przekraczających wielokrotnie tabu seksualne zależne od norm społecznych i kulturowych obecnych w ówczesnej kulturze, było związane ze zjawiskiem, które określić można mianem „kryzysu inicjacyjnego". Ten ostatni wymuszał niejako na bohaterce/bohaterze przeorientowanie własnego systemu wartości, postaw, uprzedzeń, stereotypów, wymagał dużej odwagi, a niekiedy „zagrania va banque”. Obecny w sferze marzeń seks transgresyjny (dla lat siedemdziesiątych i osiemdziesiątych mógł to być seks analny, grupowy, biseksualny, lesbijski ${ }^{9}$, a nawet seks oralny ${ }^{10}$, które stały się integralnym elementem każdej narracji pornograficznej ${ }^{11}$ ), albo w tej sferze pozostawał $^{12}$, albo też był „wdrażany” w doświadczenie bohaterki z ukazaniem jej - choćby w minimalnym wymiarze - rozterek, niepewności, które ostatecznie jednak zostają przezwyciężone i przynoszą niezwykłą rozkosz. Ta ostatnia stanowi swoistą szczególną gratyfikację za odwagę oraz „ciekawość poznawczą”13.

8 Przykładami mogą być m.in. 9 Songs, reż. M. Winterbottom, Wielka Brytania 2004; Ai no corrida (Imperium zmysłów), reż. N. Ôshima, Francja/Japonia 1976; Habitación en Roma (Noc w Rzymie), reż. J. Médem, Hiszpania 2010; Histoire d’O (Historia O), reż. J. Jaeckin, Francja/Włochy/RFN 1975; Intimacy (Intymność), reż. P. Chéreau, Francja/Hiszpania/Niemcy/Wielka Brytania 2001; La vie d’Adèle (Życie Adeli - Rozdziat 1 i 2), reż. A. Kechiche, Belgia/Francja/Hiszpania/Tunezja 2013; Nymphomaniac (Nimfomanka), reż. L. von Trier, Belgia/ Dania/Francja/Niemcy/Wielka Brytania 2013; Shortbus, reż. J.C. Mitchell, USA 2006.

9 Seks gejowski stanowił „margines” „kultury seksualnej” i był charakterystyczny dla rzeczywistych mniejszości seksualnych (tak jest do dzisiaj w tak zwanej pornografii mainstreamowej, czyli zorientowanej na odbiorcę heteroseksualnego). Seks „lesbijski” pomiędzy aktorkami stał się stałym elementem narracyjnym fabuły pornograficznej i jest właściwie obecny w każdej produkcji porno.

10 Dla kultury amerykańskiej prowincji, opartej na religii obywatelskiej, jaką jest protestantyzm ewangelikalny — popurytański, perfekcjonistyczny, z kulturą wstrzemięźliwości, w omawianym okresie każdy pozawaginalny akt seksualny, a w związku z tym znajdujący się poza kontekstem reprodukcyjnym, uznawany był za grzeszny (niekiedy demoniczny). Jeśli podejścia nie były tak „radykalne”, seks taki uważany był przynajmniej za niewłaściwy, co znalazło swój wyraz również w regulacjach prawnych na poziomie stanowym. Sytuacja ta następnie uległa zmianie. Szerzej na ten temat autor pisze oraz przytacza przykłady w: G. Wiktorowski, Model rodziny i relacji małżeńskich $w$ amerykańskim fundamentalizmie protestanckim, [w:] Problem kontroli urodzeń $i$ antykoncepcji. Krytyczno-porównawcza analiza dyskursów, red. B. Płonka-Syroka, A. Szlagowska, Wrocław 2013, s. 45-78; idem, Przezwyciężýc „świat”. Elementy transgresyjne w amerykańskim protestantyzmie fundamentalistycznym, [w:] Perspektywy poznawcze w kulturze europejskiej. Studium porównawcze, red. B. Płonka-Syroka, E.I. Rudolf, Wrocław 2012, s. 105-155.

11 Sytuacja ta jest właściwa również czasom obecnym. Charakterystyczne stałe elementy w dzisiejszej narracji pornograficznej, na przykład facial, czyli wytrysk na twarz, seks oralny techniką "głębokiego gardła" (ang. deep-throating), seks analny, grupowy, lesbijski, nie są standardowymi praktykami seksualnymi szerokich mas społecznych. Na tym poziomie pornografia kreuje rzeczywistość, tak jak inne filmy, która jest zasadniczo odmienna, choć - co należy zaznaczyć - repertuar „standardowych” zachowań seksualnych znacznie się poszerzył.

12 Oczywiście w narracji pornograficznej jest przedstawiony z najmniejszymi szczegółami.

13 O kulturowych i społecznych kontekstach rozkoszy por. m.in. Rozkosz w kulturze, red. Ł. Wróblewski, A. Giza, Kraków 2016. 
Te wymiary narracji „wypadają”, począwszy od lat dziewięćdziesiątych, a pornograficzna opowieść przesuwa się i koncentruje na samym ciele, czyniąc z niego nie tylko przedmiot narracji (jak było dotychczas), lecz także główny podmiot. Znika tym samym bohaterka/bohater z kontekstami psychoemocjonalnymi i moralnymi, a pozostaje jedynie sfera somatyczna, której granicą jest skóra oraz wydzieliny ludzkiego ciała. Zauważalne jest to w „wielkości” kadru, który coraz bardziej koncentruje się na ciele. Następuje „somatyzacja” pornografii - ciało, nie seks, staje się głównym „rozgrywającym”. Nie należy rozumieć tej tezy w sposób implikujący twierdzenie, że wcześniej ciało było nieobecne (co jest oczywiście stwierdzeniem absurdalnym) lub miało mniejsze znaczenie. Założenie to należy rozumieć w tym sensie, że ciało zwiększyło swoją obecność w sensie jakościowym — „zintensyfikowało się". Eksperymentowanie z seksem, charakterystyczne szczególnie dla lat siedemdziesiątych i osiemdziesiątych XX wieku, zamienia się w eksperymentowanie z ciałem, właściwe dla dwóch pierwszych dekad XXI wieku. Przekraczanie granic moralnych, obyczajowych i kulturowych zostało poszerzone (bądź w bardziej radykalnym ujęciu — zamienione) na projekty transgresyjne związane $\mathrm{z}$ ciałem $^{14}$.

Współczesna dyskursywizacja ${ }^{15}$ ciała jest wynikiem szeregu procesów o charakterze dyferencjacji strukturalno-funkcjonalnych oraz instytucjonalnych, na które składały się:

- przemiany społeczno-polityczne, zrywające z modelem hegemonii absolutystycznej, po której następowała powolna inkluzja i upodmiotowienie wielu grup, którym wcześniej tego statusu odmawiano (od rewolucji francuskiej z końca XVIII wieku do Wiosny Ludów z lat 1848-1849);

- przemiany gospodarcze kończące okres stosunków feudalnych, a przynoszące odpowiednio industrializację, urbanizację, technicyzację oraz wytworzenie w XX wieku kultury konsumpcyjnej;

- przemiany w nauce i technice, a w zasadzie rewolucja epistemiczna, zrywająca z hegemonią eksplanacyjno-interpretacyjną Kościołów chrześcijańskich ${ }^{16}$ (począwszy od oświecenia rozpoczętego w końcu XVII wieku, przez zmiany w przy-

14 Szeroko autor pisze o tym w artykule, w którym wyróżnił 922 kategorie pornografii internetowej (klasyfikacja ta nie ma, co ważne, charakteru zamkniętego, ostatecznego), w której znaczna ich część koncentruje się na samym ciele i jego aspektach oraz funkcjach, a w mniejszym stopniu na zachowaniach. Por. G. Wiktorowski, Pornografia — od medykalizacji do „nozologicznej" precyzji na przykładzie pornografii internetowej, [w:] Miłość niemożliwa, red. B. Płonka-Syroka, A. Szlagowska, Wrocław 2016, s. 225-273.

15 Dyskurs autor definiuje jako jedną z form rozumienia rzeczywistości wyrażaną poprzez język. Wytwarza on jej znaczenie w procesie bezustannej negocjacji. Nie jest tym samym uniwersalny, lecz konstruowany kulturowo i społecznie. W związku z tym uznaję go za twór tworzony, a nie odkrywany (rozumienie pomiędzy Michelem Foucaultem a Richardem Rortym). Ma charakter procesu społecznego o funkcji poznawczej, zapośredniczonego językowo i symbolicznie.

16 Proces ten zapoczątkowała w XVI wieku reformacja protestancka (a wcześniej także protoprotestantyzm), demonopolizując hegemonię epistemiczną Kościoła i uruchamiając tendencje 
rodoznawstwie dokonane poprzez teorię ewolucji w drugiej połowie XIX wieku, skończywszy na ogłoszeniu szczególnej, a następnie ogólnej teorii względności na początku XX wieku, która ukonstytuowała paradygmat relatywistyczno-konstruktywistyczny dwudziestowiecznej nauki) ${ }^{17}$.

Procesy te przyniosły zmiany demograficzne, społeczne, kulturowe, świadomościowe, obyczajowe, poznawcze, estetyczne, ekonomiczne i polityczne. Wyraziły się one $-\mathrm{w}$ interesujących nas kontekstach $-\mathrm{w}$ aktywizacji ruchów kobiecych, a następnie innych grup uprzednio wykluczonych i marginalizowanych społecznie i kulturowo; przedefiniowaniem modelu rodziny, małżeństwa, relacji interpersonalnych w związkach; redefinicją seksualności i oderwaniem jej wpierw od kontekstu reprodukcyjnego (niezależność funkcjonalna seksu), co stało się możliwe w latach sześćdziesiątych XX wieku wraz z wprowadzeniem antykoncepcyjnej pigułki hormonalnej ${ }^{18}$, następnie małżeńskiego, a w ostateczności emocjonalno-uczuciowego; jak również w przemianach związanych z medykalizacją, farmakologizacją, technicyzacją oraz estetyzacją życia codziennego. W powyższych kontekstach ciało stawało się każdorazowo podmiotem społecznej wyobraźni, raz jako ciało płciowe, innym razem jako ciało seksualne, jeszcze innym jako ciało symboliczne. Upodmiotowieniu i dyskursywizacji uległo także ciało nienarodzone, w okresie prenatalnym ${ }^{19}$.

Aspektem czy też wymiarem zmian, którym uległo „nowożytne ciało”, na którym chcemy się skoncentrować, jest jego medykalizacja. Za amerykańskim socjologiem Peterem Conradem możemy stwierdzić, że jest to proces, w którym nadajemy status medyczny problemom pierwotnie niemedycznym, traktując je w kategorii chorób bądź zaburzeń ${ }^{20}$. Medykalizacja przekroczyła jednakże granice ciała oraz jego stanów i zmian, przechodząc od kontroli jego funkcji oraz parametrów fizjologicznych do szerszych aspektów politycznych, społecznych czy moralnych ${ }^{21}$. „Przemedykalizowanie” (ang. overmedicalization) zachowań,

pluralistyczne legitymizujące współzawodnictwo pomiędzy grupami religijnymi, z czego następnie wytworzył się pluralizm światopoglądowy.

17 Szerzej por. m.in. teksty zebrane w Nauka i społeczeństwo w stulecie szczególnej teorii względności Alberta Einsteina (1905-2005), red. B. Płonka-Syroka, Warszawa-Wrocław 2006.

18 Szerzej por. m.in. teksty zebrane w Kobieta i małżeństwo. Społeczno-kulturowe aspekty seksualności. Wiek XIX $i$ XX, red. A. Żarnowska, A. Szwarc, Warszawa 2004; Kobieta i praca. Wiek XIX i XX, red. A. Żarnowska, A. Szwarc, Warszawa 2000; Kobieta i rewolucja obyczajowa. Społecznokulturowe aspekty seksualności. Wiek XIX i XX, red. A. Żarnowska, A. Szwarc, Warszawa 2005; B. Płonka-Syroka et al., Zjawisko antykoncepcji w perspektywie społecznej i historycznej, Wrocław 2012.

19 Autor pisał o tym w: G. Wiktorowski, Sposoby mówienia o aborcji. Implikacje ideowe dyskursu naukowego iświatopogladowego, [w:] Problemy zdrowia reprodukcyjnego kobiet, t. 1. Wstęp do badań, red. A. Szlagowska, Wrocław 2016, s. 37-65.

20 Por. P. Conrad, Medicalization and social control, „Annual Review of Sociology” 18, 1992, nr 1, s. 209-232.

21 Por. Z. Słońska, M. Misiuna, Promocja zdrowia. Słownik podstawowych terminów, Warszawa 1993, s. 21. 
stanów czy emocji jest obecnie krytykowane w naukach społecznych ${ }^{22}$. W tym miejscu termin ten rozumiemy jednakże w sposób neutralny (opisowy) - nawiązując tym samym do definicji brytyjskiego historyka medycyny Paula Weindlinga - jako rozprzestrzenianie się standardów współczesnej medycyny klinicznej na inne przestrzenie działań społecznych ${ }^{23}$. Podejście to jest zgodne ze standardem interpretacyjnym antropologii wiedzy reprezentowanym w niniejszym opracowaniu, który widzi proces medykalizacji choroby i ciała jako projekt dążenia do ograniczenia wpływu elementów światopoglądowych (zewnątrznaukowych) na postrzeganie choroby i ciała, i sprowadzenie ich do poziomu analizy opartej o kategorie somatyczne, a nie metafizyczne. Rozpatrywanie genezy zjawisk chorobowych oraz aspektów funkcjonalnych ludzkiego organizmu ma opierać się na interpretacji przyczynowej, a nie celowej (teleologicznej). Medykalizacja zatem dokonywała przemiany paradygmatu oraz związanej z nim świadomości społecznej w kierunku profesjonalnego dyskursu klinicznego. Zmiana taka nastąpiła wraz z tak zwanym przełomem nowożytnym w medycynie europejskiej, który nastąpił dwukrotnie.

Pierwszy (związany z 1750 rokiem) dotyczył wprowadzenia nowego (w stosunku do poprzednich) standardu teoretyczno-metodologicznego w oficjalnych instytucjach oraz uniwersytetach medycznych ${ }^{24}$. Fundamentalne dla nowego standardu było odwołanie się do doświadczenia oraz obserwacji, które mają cechy weryfikowalne i powtarzalne. Podmiot poznający odgrywał w tych procedurach zasadniczą rolę. Tworzenie nowych hipotez naukowych implikowało jego aktywny udział, w przeciwieństwie do wcześniejszych standardów, w których postrzegano ów udział jako pasywny. Ostatecznie został on zakwestionowany w drugiej połowie XVIII wieku na rzecz przekonania o swobodzie stawiania przez uczonych hipotez naukowych, których zadaniem jest rozwiązywanie aktualnych sytuacji

22 Por. P. Conrad, The Medicalization of Society: On the Transformation of Human Conditions into Treatable Disorders, Baltimore 2007, s. 6; E. Banaszak, R. Florkowski, Medykalizacja jako forma dyskursu o ciele, „Fizjoterapia” 2010, nr 3, s. 25-33. Sytuacja ta prowadzi również - niestety - do podważania ogólnego standardu i zaufania do biomedycyny, co staje się wyjątkowo niebezpieczne. Aspekty antymedyczne, a szerzej antyracjonalne i antynaukowe, prowadzą do powstawania różnorakich ruchów kontestujących, $\mathrm{w}$ tym na przykład odmawiających szczepień (tak zwane ruchy antyszczepionkowe), co z kolei prowadzi do tworzenia wyłomów w systemie zabezpieczeń przeciwepidemicznych i higienicznych, tworzonych przez wiele wieków (w zasadzie od starożytności, choć nieskutecznie), a ukończonych dopiero po II wojnie światowej.

${ }^{23} \mathrm{Za}$ : R.A. Nye, The evolution of the concept of medicalization in the late twentieth century, „Journal of the History of the Behavioral Sciences” 39, 2003, nr 2, s. 117.

${ }^{24}$ Szerzej por. m.in. Proces modernizacji nauk przyrodniczych w historii i historiografi nauki, red. B. Płonka-Syroka, Wrocław 2003; Przełom nowożytny w nauce europejskiej i jego kontekst społeczno-kulturowy, red. B. Płonka-Syroka, Wrocław 2004; B. Płonka-Syroka, G. Wiktorowski, Kształtowanie się standardu antropologii medycyny klinicznej w niemieckim i anglosaskim piśmiennictwie naukowym. Zarys zagadnienia, [w:] Podstawy interdyscyplinarności w naukach o zdrowiu. Poznawcza tożsamość dyscyplin badających socjokulturowy wymiar zdrowia i choroby, red. M. Skrzypek, Lublin 2014, s. 215. 
problemowych możliwych do rozwikłania w kontekście aktualnego stanu wiedzy. Drugi etap rozpoczyna się w 1850 roku, kiedy to, wdrażając wspomniane reformy na wydziałach lekarskich, położono podwaliny pod nową sytuację problemową bakteriologii oraz dokonano podziału medycyny wewnętrznej na poszczególne specjalizacje $\mathrm{e}^{25}$.

Medycyna kliniczna, która po przełomie nowożytnym może być ze spokojem określana jako „nowa” ${ }^{26}$, przystąpiła do budowy własnego standardu, a w przestrzeni „zewnętrznej”, w stosunku do niej - do jego upowszechniania. Standard ten został ograniczony jedynie do elementów somatycznych. Sytuacja ta wystąpiła również $\mathrm{w}$ rozwijającej się psychiatrii, która została oparta na podstawach neurologicznych. W tym wypadku somatyzacja doprowadziła do oddzielenia się psychologii. Psychiatria kliniczna nie rozpatrywała już zaburzeń psychicznych jako patologii duszy, ale jako procesy somatyczne o aberracyjnym przebiegu. Psychologia natomiast podążyła w stronę interpretacji „pedagogicznych” (zaburzenia jako wynik błędów wychowania) oraz „egzystencjalnych” (zaburzenia jako skutek problemów życiowych czy zdarzeń traumatycznych). Postulatorzy standardu somatycznego dążyli ponadto do uwolnienia medycyny od wpływów teologii i antropologii metafizycznej, które do przełomu nowożytnego w nauce były nadrzędne $\mathrm{w}$ stosunku do akademickiej filozofii przyrody ${ }^{27}$, i związania jej z naukami przyrodniczymi. Somatycy postrzegali chorobę w kategoriach funkcjonalnych, a zatem poszukiwali czynnika, który miał wywoływać zmianę chorobową. Podejście to doprowadziło do wytworzenia nowej sytuacji problemowej, a mianowicie potrzeby wykazania zależności pomiędzy budową anatomiczną a funkcją narządu, tkanki, czy później komórki. Na gruncie psychiatrii postawiono następujące pytania badawcze: „które czynniki materialne są źródłem zaburzeń oraz czy można je wyeliminować, a zatem wdrożyć jakieś procedury terapeutyczne pozwalające zapobiegać chorobom psychicznym?"28.

Program somatyków był przejściem od „słuchania kosmosu” do „słuchania ciała". W tej perspektywie etiologia chorób jawiła się jako materialistyczna, a zatem naturalna, a ustalenie jej przyczyny stało się głównym celem działań medycznych. To ostatnie zostało oparte na wnioskowaniu przyczynowym, a nie teleologicznym. „Naturalizacja” choroby przebiegała równocześnie (szczególnie w XIX wieku) z „naturalizacją" ciała. W związku z tym choroba niebyła już postrzegana jako manifestacja

25 Por. B. Płonka-Syroka, op. cit., passim.

26 Oczywiście rozumiemy ją w perspektywie historycznej ciągłości jako skutek działań poprzedzających. Nie postrzegamy zatem „zmiany paradygmatu” jako wyniku swoistego oświecenia o charakterze metafizycznym. Przymiotnik „nowa” wskazuje na nowy standard teoretyczny, który jednakże zawierał wiele elementów wcześniejszych podejść, które w ciągu dalszego rozwoju były eliminowane.

27 Szerzej problem ten omawia E. Grant, Średniowieczne podstawy nauki nowożytnej w kontekście religijnym, instytucjonalnym oraz intelektualnym, Warszawa [2005].

28 Por. B. Płonka-Syroka, op. cit., s. 212-213. 
woli sił nadprzyrodzonych. „Naturalizacja” ciała zrywała natomiast z jego percepcją jako przestrzeni walki kosmicznej pomiędzy siłami dobra i zła bądź jako przestrzeni zależnej od wpływu sił kosmicznych w postaci cyklów zodiakalnych, planetarnych czy okresów klimatycznych związanych z następstwami ruchu obiegowego Ziemi wokół słońca (pory roku). „Naturalizacja” ciała jest zatem procesem „sprowadzenia" go na ziemię, co wyraziło się w mechanizmach desakralizacji, detabuizacji, a ostatecznie sekularyzacji ciała ${ }^{29}$.

Zsekularyzowane ciało stało się przestrzenią wielu projektów o różnorodnym charakterze, szczególnie biologiczno-anatomicznym. Pozbawione pierwiastka świętości bądź demoniczności, lecz także boskiej emanacji (por. koncepcje Pięciu Ran Męki Pańskiej, tłoczni mistycznej czy ciała eucharystycznego ${ }^{30}$ ) ciało mogło zostać poddane kolejnym etapom "dyskursywizacji” naukowej. Mierzone, ważone, badane, $\mathrm{z}$ określanymi wciąż na nowo parametrami anatomicznymi, fizjologicznymi, morfologicznymi, genetycznymi, ale też psychologicznymi, behawioralnymi czy sprawnościowymi. Medykalizacja zaczęła kolonizować nie tylko sfery somatyczne na wszystkich poziomach (narządy, tkanki, komórki, geny), lecz także w różnych jego wymiarach: psychicznym i emocjonalnym (medykalizacja zachowań, emocji, uczuć, stanów psychoemocjonalnych), tożsamościowym (medykalizacja tożsamości płciowej, seksualnej; medykalizacja płci - w wypadku kobiet medykalizacja menstruacji, ciąży i porodu, macierzyństwa, menopauzy), funkcjonalnym (medykalizacja płodności, reprodukcji, wytrzymałości, sprawności fizycznej, wydolności), rozwojowym (medykalizacja embriogenezy, płodu i okresu prenatalnego, dzieciństwa, dojrzewania, starości, śmierci) czy choćby estetycznym (medykalizacja dysfunkcji organicznych, niepełnosprawności, niedoskonałości w wyglądzie, związanych również z brakiem akceptacji własnej).

Tak rozumiane ciało już od końca XIX wieku uzyskało status „przestrzeni oswojonej", percypowanej w kategoriach naturalistycznych i materialistycznych. Charakter metafizyczny i moralny utrzymało jeszcze w kontekstach religijnych oraz wynikających $\mathrm{z}$ nich uniwersów poznawczych w postaci wizji świata czy racjonalności i świadomości potocznej. Jednakowoż i na tym gruncie zaszły pewne zmiany. W purytańskich w zasadzie (charakteryzujących się kulturą wstrzemięźliwości i wstydu) społeczeństwach Europy XIX wieku „dyskursywizacja” naukowa

29 Szerzej o historii ciała do XIX wieku por. m.in.: Historia ciała, t. 1. Od renesansu do oświecenia, red. G. Vigarello, przeł. T. Stróżyński, Gdańsk 2015, passim; Historia ciała, t. 2. Od Rewolucji do I wojny światowej, red. A. Corbin, przeł. K. Belaid, T. Stróżyński, Gdańsk 2013; G. Vigarello, Historia zdrowia i choroby. Praktyki sanitarne od średniowiecza do współczesności, Warszawa 2011. $\mathrm{O}$ tych aspektach w kontekście pornografii piszą m.in. E. Banaszak, R. Florkowski, Intymne, prywatne, publiczne. O częściach ciała, które należy zakrywać..., [w:] Moralne obrazy. Społeczne i socjologiczne (de)konstrukcje seksualności, red. E. Banaszak, P. Czajkowski, Wrocław 2008, s. 11-41; E. Banaszak, R. Florkowski, Krótki kurs pornografii w kulturze popularnej, [w:] Moralne obrazy..., s. $65-85$.

${ }^{30}$ Por. J. Gélis, Ciało, Kościót, sacrum, [w:] Historia ciała, t. 1, s. 15-95. 
ciała i seksualności zderzyła się z przemianami społeczno-ekonomicznymi, które wytwarzały coraz szerszą klasę mieszczańską. Umożliwiło to nauce przełamanie oporu środowisk religijnych, których celem było utrzymanie obowiązującego status quo ciała i seksualności oraz „podgrzewanie” strachu przed nimi. Odnoszące liczne sukcesy mieszczaństwo coraz częściej podejmowało dyskursy proponowane przez naukę akademicką, ze zrozumiałych celów o charakterze „merkantylnym”. Rozwijające się przedsiębiorstwa, miasta i instytucje wymagały coraz bardziej szczegółowej racjonalizacji, wyjaśniającej zasady, reguły, procesy i mechanizmy działania. Mieszczaństwo podjęło również kwestię pozytywistycznej psychiatrii, proponującej etykę opartą na modelach epistemicznych, zasadzających się na nauce, a nie religii. Psychiatryczny standard interpretacyjny został wsparty w drugiej połowie XIX wieku przez darwinizm, który wprowadził do dyskursu naukowego „paradygmat zwierzęcości”. Ten ostatni wpłynął na późniejsze konkluzje, które przemodelowywały strukturę myślenia kolejnych grup społecznych. Proces ten przebiegał w kontekście następującego continuum eksplanacyjno-interpretacyjnego - skoro człowiek jest „wytworem” procesu ewolucji (która w niektórych rozstrzygnięciach religijnych może mieć charakter determinowany przez Boga), a zatem jest uwarunkowany instynktami biologicznymi, nie może sprzeciwiać się Bogu, tudzież naturze przez niego stworzonej, ulegając własnej popędliwości ${ }^{31}$.

„Naturalizacja” choroby i ciała, jeśli nie usunęła wszelkich elementów o charakterze metafizycznym, na pewno dokonała ich redefinicji. Rozumowanie klinicystów sprzeciwiało się ujmowaniu choroby w kategoriach moralnej odpowiedzialności, wyrażającej manifestację boskiej woli w postaci kary. Odejście od kulpabilizacji choroby ${ }^{32}$ otworzyło drogę dla programów profilaktycznych, które nie sprzeciwiają się już „wyrokom bożym”, ale z nimi „współpracują” w celu zachowania ciała w stanie „naturalnej”, a zatem boskiej, homeostazy. Zdolność utrzymywania stałości parametrów wewnętrznych stanie się pod koniec XX wieku istotnym dla społeczeństw zachodnich celem (zarówno jeśli chodzi o chorobę, jak i wygląd oraz wydolność ciała).

Somatyzacja choroby i ciała, oparta na procedurach obserwacji oraz pomiaru parametrów, rodzi potrzebę katalogowania, kodyfikacji określonych zespołów symptomatologicznych oraz wytworzenia kodeksów parametrycznych na wzór urzędniczych repozytoriów. Opisanie i przechowywanie każdego zaburzenia staje się swoistym mitem założycielskim fetyszystycznej w swej naturze nozologii medycznej. Podobnie jest współcześnie w wypadku pornografii internetowej dostępnej w serwisach pornograficznych oferujących skatalogowane "ciała pornograficzne” oraz rodzaje zachowań, niczym w seksualnym „ogrodzie zoologicznym”, w którym eksponowane są niezliczone ilości gatunków i wariacji przyrody na temat

31 Por. G. Wiktorowski, Pornografia - Not a Love Story? Meandry paradygmatycznych przeinaczeń: miłość, seks, ciało, gender, medykalizacja, [w:] Miłość niemożliwa, s. 217.

32 Tu: przekonanie, że choroba jest konsekwencją kary bożej za winy czy grzechy. 
biologicznych popędliwości. Film pornograficzny jawi się tutaj jako gatunek kina przyrodniczego, którego głównym celem jest ukazanie mechaniki kopulacji ${ }^{33}$. Zatrzymajmy się jednak na chwilę przy internetowych katalogach z pornografią. Portale te stają się nie tylko metaforycznym ogrodem zoologicznym, w którym można oglądać „rzędy, rodziny, rodzaje, gatunki czy rasy” zachowań seksualnych i ciał, lecz także swoistymi „świątyniami rozkoszy”, w których immanentna cecha bóstwa, jaką jest „święte szaleństwo"34, objawia się wśród wiernych (konsumentów, oglądaczy) „szaleństwem widzialności”, używając języka amerykańskiej filmoznawczyni Lindy Williams ${ }^{35}$. Widzialność ciała jest podstawowym aspektem umożliwiającym jego empiryczne badanie, obserwację, a w konsekwencji - edukację i doświadczanie za pośrednictwem wzroku. Katalogi internetowe przypominają tradycyjne katalogi biblioteczne, porządkujące przechowywane piśmiennictwo według różnego rodzaju kluczy (porządek alfabetyczny, ze względu na autora, epokę, reprezentowaną dyscyplinę, zakres problemowy i tematyczny, czy przeznaczenie). Stanowią zatem swoistą bibliotekę seksuologiczną i seksiatryczną, w której katalogowane są wszystkie akty i ciała, w pełnym spektrum ich różnorodności, aspektowości, odmienności. Widzialność wytwarza, oprócz wiedzy, również relacje władzy, których modele zaproponował między innymi Michel Foucault ${ }^{36}$. W kontekście kultur męskocentrycznych (patriarchalnych) to męskie spojrzenie wytyczało kierunki fabularne, ujarzmiając i fetyszyzując nie tylko ciało i seksualność kobiety, lecz także każdy ich aspekt czy wymiar. Męska reżyseria kobiecych cia ${ }^{37}$ dokonała $\mathrm{w}$ pornografii i przez pornografię kodyfikacji ciała kobiecego, kategoryzując, porządkując, taksonomizując jego pofragmentowane, zdekapitowane ${ }^{38}$ części według fetyszystycznych upodobań. Wyprzedziła tym samym „klasyka gatunku”, za którego uznany jest austriacko-niemiecki seksuolog, psychiatra i kryminolog Richard von Krafft-Ebing, który w 1886 roku wydał ponad sześćsetstronicową książkę porządkującą oraz opisującą według ówczesnego stanu wiedzy i mianownictwa dewiacje seksualne ${ }^{39}$.

33 Por. G. Wiktorowski, Pornografia - od medykalizacji..., s. 225-273.

34 Szerzej por. J. Sieradzan, Szaleństwo w religiach świata. Szamanizm, religia starogrecka, judaizm, chrześcijaństwo, hinduizm, buddyzm, islam, Kraków 2007.

35 Por. L. Williams, op. cit., passim.

36 Por. m.in. M. Foucault, Podmiot i władza, przeł. J. Zychowicz, „Lewą Nogą” 1998, nr 10, s. 178 n. Za zwrócenie uwagi na te aspekty dziękuję dr. hab. Lechowi M. Nijakowskiemu z Instytutu Socjologii Uniwersytetu Warszawskiego.

37 Por. A. Corbin, Spotykanie się ciał, [w:] Historia ciała, t. 2, s. 175.

38 Tu: wycięte, wyabstrahowane, odłączone od swojego kontekstu, czyli reszty ciała.

39 Por. R. von Krafft-Ebing, Psychopathia Sexualis, with Especial Reference to Contrary Sexual Instinct: A Medico-Legal Study, Philadelphia-London 1893 (to amerykańskie tłumaczenie liczy 436 stron). Z kolei indyjski profesor medycyny sądowej Anil Aggrawal opisał 547 rodzajów parafilii: idem, Forensic and Medico-legal Aspects of Sexual Crimes and Unusual Sexual Practices, Boca Raton 2009; por. także 922 kategorie pornografii internetowej zebrane w: G. Wiktorowski, Pornografia od medykalizacji..., s. 225-273. 
Podążając dalej tym tropem interpretacyjnym, uwzględniając sukces, jaki odniesiono upowszechniając kliniczny standard medyczny, musimy stwierdzić, że współczesne ciało doznało całkowitego, zupełnego odczarowania. Odarte ostatecznie z resztek magii, świętości, tajemnicy i poddane materialistycznej oraz racjonalistycznej reifikacji stało się w kontekstach pornograficznych nie tyle elementem pierwszym i podstawowym, konstytuującym tożsamość jednostki oraz elementarną część nowoczesnego projektu antropologicznego (samoposiadanie, samostanowienie, ukierunkowanie na przyjemność), ile w dużej mierze mięsem-rzeczą, którą należy postrzegać i badać narzędziami właściwymi standardowi interpretacyjnemu antropologii rzeczy. Unaukowienie podejścia i rozumienia ciała, ale też seksualności, wywołało również reakcję odejścia od mechanizmów tradycji regulujących reprodukowanie porządku społecznego w stronę koncentracji na jednostce, której indywidualne wybory mają zapewnić spełnienie i samorealizację. Klęska wielkich religijnych, moralnych i politycznych narracji wzmocniła znaczenie świadomości ciała ${ }^{40}$. Innymi słowy, chodzi o lepsze samopoznanie na poziomie somatycznym, a w kontekście pornografii - o zwiększenie skali własnej wrażliwości. Rozpoznanie tych mechanizmów pozwala na udane gospodarowanie procesami stymulacji i bodźcowania $\mathrm{w}$ celu osiągania coraz to intensywniejszych i jakościowo „lepszych” dróg uzyskiwania rozkoszy. „Odmagicznienie” i urzeczowienie ciała przebudowuje także koncepcję antropologiczno-tożsamościową. We współczesnej pornografii self (ja) ma wymiar jedynie somatyczny, materialistyczny, dekonstruując, a w konsekwencji niszcząc (znosząc) jego wymiary pozasomatyczne (psychoemocjonalny, moralny, duchowy). Dokonuje też pewnego zwrotu epistemicznego - człowiek jako podmiot pornografii kieruje swoją uwagę z orbis exterior (konteksty psychologiczne, społeczno-kulturowe, moralne, istniejące ponadjednostkowo) do orbis interior, którego swoistym limes jest skóra. Celem tego zwrotu ma być lepsze poznanie samego/samej siebie (self), własnych możliwości, ograniczeń czy wrażliwości na bodźce. Klęska wspomnianych narracji ${ }^{41}$ „skłania do inwestowania w fizyczność jednostki [...]; wprowadza umiejętność panowania nad sobą, całkowicie podporządkowaną trosce o ciało", jak stwierdza francuski historyk i socjolog Georges Vigarello ${ }^{42}$.

Nowy projekt antropologiczno-tożsamościowy ukazuje swoiste „uzależnienie" człowieka od permanentnej transgresji, co zauważyli socjolodzy niemieccy, pisząc:

w rzeczy samej permanentna „etyka zmiany” została wprawiona w ruch [...]. Dotychczasowe bariery ograniczające ludzi - prawa natury, słowo Boga, społeczne obyczaje i imperatywy klasowe - sukcesywnie zanikają i w rezultacie nie ma już żadnych reguł mówiących „stop”.

40 Por. G. Vigarello, op. cit., s. 339.

41 Należy pamiętać, że procesy te są zmienne, „nic nie jest dane raz na zawsze”, i przy zmieniających się kontekstach politycznych mogą zwrócić się do swoich podstaw, źródeł, korzeni.

42 G. Vigarello, op. cit., s. 339. 
Zamiast tego normą staje się poszukiwanie czegoś więcej: jeszcze szybszego, większego i piękniejszego ${ }^{43}$.

Transgresja w pornografii nie zatrzymuje się już na ukazaniu w dużych zbliżeniach powierzchni ciała, odsłaniając jego morfologię, ale i drobne niedoskonałości, ani także na tak zwanych meat shotach, czyli zbliżeniach i powiększeniach narządów płciowych, szczególnie w sytuacji penetracji, lecz poprzez „styl prześwietlający", który w produkcjach animowanych i animacji komputerowej wchodzi do wnętrza organizmu, ukazując szczegóły anatomii wewnętrznej, niewidocznej dla oka, dokonując tym samym pornograficznej „sekcji”, autopsji. Ten ostatni termin podkreśla również aspekty wizualne.

Powróćmy jednakże na powierzchnię skóry. Ciało w pornografii „somatycznej" jest wyidealizowane, wytresowane, wysportowane, atrakcyjne fizycznie oraz zdrowe (wyjąwszy kategorie pornograficzne związane $\mathrm{z}$ fetyszystyczną dysmorfofilią, akrotomofilią czy choćby abasiofilią). Wszelkie niedoskonałości zostają zatuszowane przez makijaż, oświetlenie i inne zabiegi kosmetyczne. Takie ciało filozofka Jolanta Brach-Czaina nazywa „atrapą ciała” ${ }^{4}$. Estetyzacja ciała pornograficznego jest „osiągnięciem” ostatnich dekad i jest związana z profesjonalizacją przemysłu pornograficznego. Wcześniej nie przykładano większego znaczenia do estetycznego wyglądu ciała, gdyż najważniejsze było samo przedstawienie aktu seksualnego. Obecnie dotyczy to szczególnie pornografii amatorskiej. Ciało pornograficzne ukazywało całą swoją strukturę, morfologię, wszelkie niedoskonałości (siniaki, pryszcze, żylaki, owłosienie, tłustą cerę). Seksuolog Zbigniew LewStarowicz podsumował tę sytuację w trochę zabawny sposób: „[k]iedyś pornografia była [...] sprzedawana po cichu na bazarze Różyckiego. Aktorzy mieli zakazane mordy: ona prymitywna, on pięć lat bez prokuratora, cały w krostach. Aż odrzucało człowieka!" ${ }^{5}$. Wraz z przejściem w pornografii „somatycznej” od seksu do ciała w kontekście aktywności seksualnej poczyniono zabiegi estetyzacyjne.

Ciało pornograficzne to nie tylko ciało estetyczne, dobrze zbudowane, lecz także ciało zdrowe ${ }^{46}$. Lekkie, gładkie, opalone - jawi się jako kwintesencja witalności. Lekkość ma ukazywać aspekty zdrowego stylu/trybu życia, stosowanie zaleceń dietetycznych czy uprawianie aktywności fizycznej. Gładkość implikuje aspekty higieniczne, w których depilacja obecnie otrzymuje status jednego z podstawowych zabiegów. Opalenizna wskazuje na wymiary dbałości nie tylko

43 U. Beck, E. Beck-Gernsheim, The Normal Chaos of Love, Cambridge 1995, s. 92-93; przekład cyt. za: M. Musiał, Intymność i jej współczesne przemiany. Studium z filozofii kultury, Kraków 2015, s. 65.

44 Por. J. Brach-Czaina, Ciało współczesne, „Res Publica Nowa” 2000, nr 11, s. 5.

45 A. Fedorczuk, B. Marczuk, Pornografia pustoszy mózgi dzieci, rozmowa z prof. Z. Lwem-Starowiczem, „Wprost” 2015, nr 46, s. 74.

46 Por. m.in. M. Bieńko, O ponowoczesnych przygodach zdrowego i chorego ciała w perspektywie nauk społecznych, [w:] W zdrowiu i w chorobie... Z badań antropologii medycznej i dyscyplin pokrewnych, red. D. Penkala-Gawęcka, I. Main, A. Witeska-Młynarczyk, Poznań 2012, s. 29-44. 
o estetykę, ale też kondycję, odpoczynek, regenerację. Wszystkie te przedsięwzięcia są przejawami ostatniego paradygmatu medykalizacji życia w różnych aspektach jego funkcjonowania i związane są z tak zwaną medycyną estetyczną, którą niekiedy można by określić mianem medycyny kosmetycznej. Zdrowe ciało to również ciało wydolne i sprawne seksualnie. „Orgazmiczna” atmosfera wymaga wytrzymałości oraz kondycji fizycznej. Zapewniając swojej partnerce „maraton" orgazmów, ciało partnera (dotyczy to penetracji) musi posiadać parametry wydolnościowe, które mu na to pozwolą. Choć ciało pornograficzne poddane jest pewnym rygorom dietetycznym, estetycznym, kultury fizycznej, nie ulega jednakże nakazom dawnych praktyk dyscyplinujących, jak gimnastyka czy restrykcyjna dieta, które stanowily element polityki higienicznej państwa i sterowane były przez odpowiednio do tego delegowane jednostki władzy centralnej ${ }^{47}$. Obecne „rygory” mają charakter demokratyczny, zależny od woli, wyboru i decyzji konkretnej jednostki. Są w rzeczy samej hedonistyczne, a nawet narcystyczne, i tym cechom podporządkowane. Jeśli im służą, są podtrzymywane (dieta, siłownia, fitness).

Co należy podkreślić, ciało pornograficzne jest relatywne. Transgresyjnie wykracza, a nawet przełamuje normatywne wzorce zdrowia i estetyki ciała współczesnego z kontekstów niepornograficznych. Stwierdzenie to nie podważa tego, co zostało powiedziane, gdyż stosowane jest w ściśle określonych warunkach i dotyczy kontekstów fetyszystycznych. Ciało zbyt szczupłe lub otyłe może nie być postrzegane przez pryzmat zaleceń medycznych czy wzorców mody dominujących w kulturze, ale właśnie w perspektywie subiektywnych upodobań fetyszystycznych. Przykładem mogą być kategorie pornografii internetowej, wśród których można wymienić między innymi: BBW (akronim od Big Beautiful Women „wielkie piękne kobiety”), SSBBW (akronim od Super-Sized Big, Beautiful Woman — „przesadnie wielkie piękne kobiety”) ${ }^{48}$ czy choćby skinny, slim, thin („chuda”, „szczupła” $)^{49}$.

$\ddot{*} *$

Podsumowując powyższe rozważania, należy stwierdzić, że medykalizacja jest ważnym czynnikiem w projektowaniu podejścia i rozumienia ciała we współczesności (ponowoczesności, późnej nowoczesności). Postawiona we wstępie teza o przesunięciu, jakie nastąpiło w pornografii z ukazywania samego aktu seksualnego w różnych układach i kontekstach, włącznie z pewnymi wymiarami emocjonalno-psychologicznymi, w stronę prezentowania ciała w kontekście aktywności

47 Szerzej por. G. Vigarello, op. cit., s. 217-238.

48 Aktorki o wadze powyżej $400 \mathrm{lbs}$ (czyli ponad $180 \mathrm{~kg}$ ).

49 Szerzej por. G. Wiktorowski, Pornografia - od medykalizacji..., s. 234. 
seksualnej, bez tych wymiarów (począwszy od lat dziewięćdziesiątych XX wieku), implikuje właśnie to przekonanie, które widzi w medykalizacji jeden $\mathrm{z}$ istotnych czynników zmiany we współczesnej historii ciała.

"Somatyzacja” pornografii wpływa również na reprezentacje samego seksu i wywołane tym przesunięcia $\mathrm{z}$ wymiarów technicznych, ukazujących metody, praktyki i sposoby uprawiania seksu, które można postrzegać także w kategoriach edukacyjnych, do wymiarów technologicznych, zintegrowanych z obiektem, surowcem, materiałem, na którym się pracuje, z którego coś się wytwarza, a którym w tym wypadku jest ciało.

„Technologia” seksu wyabstrahowuje go z wymiarów emocjonalnych i uczuciowych, ukazując jedynie mechanikę działania, a - używając mianownictwa medycznego - prezentuje go w warunkach klinicznych, podkreślając i eksponując jego aspekty biologiczno-anatomiczne. Tym samym ciało pornograficzne staje się mięsem wystawionym na rzeźniczym stole lub preparatem anatomicznym, którym można przyglądać się, rozpoznając ich fizjonomię (wygląd zewnętrzny), morfologię (budowę wewnętrzną i zewnętrzną), fizjologię (czynności życiowe) czy histologię (czynności tkanek). Jako "mięso" ciało zostaje poddane determinizmom fizjologicznym i biologicznym, stając się pod koniec XX wieku podstawową prawdą, ukazującą na poziomie materialnym wymiary desakralizacji świata i ciała, a na poziomie symbolicznym utratę autorytetu wielkich idei i wartości. Tym samym ciało staje się fetyszem ${ }^{50}$, materialnym zapośredniczeniem treści symbolicznych, obiektem kultu, adoracji, uwielbienia i czci, chciałoby się rzec nabożnej, to znaczy podszytej lękiem przed nierozpoznawalnym już numinosum ${ }^{51}$. Ciało odmagicznione, zsekularyzowane stało się jednowymiarowe, pozbawione pierwiastka transcendentnego, utrzymało jedynie wymiar materialny, który ma budzić wyłącznie pożądanie, podniecenie, rozbudzać zmysły. Cała semantyka ciała została sprowadzona do jego zmysłowości i „fizycznej somatyczności” ${ }^{2}$. Dokonująca się w ten sposób depersonalizacja seksu i ciała ukazuje zwrot w procesie upodmiotawiania, jaki dokonywał się przynajmniej w dwóch ostatnich stuleciach. Depersonalizacja seksu pomija podmiotowość osób biorących udział w akcie. Upodmiotowione ciało zaś na powrót staje się „tylko” ciałem, „workiem na narządy", pozbawionym wymiarów, które w perspektywach esencjalizmu antropologicznego postrzegane były jako istotowe dla konstytucji człowieka i człowieczeństwa. Utrzymało jednakże cechę, którą udało się nabyć, a niekiedy wywalczyć w długim procesie upodmiotawiania, a którą jest samoposiadanie. Współczesne ciało, także to pornograficzne (wykluczywszy wątki przestępcze, przymusu, wykorzystania czy handlu ludźmi, których w tym miejscu nie poruszamy), to ciało

\footnotetext{
50 Nowsze ujęcia por. H. Böhme. Fetyszyzm i kultura. Inna teoria nowoczesności, przeł. M. Falbowski, Warszawa 2012.

51 Por. R. Otto, Świętość. Elementy irracjonalne w pojęciu bóstwa i ich stosunek do elementów racjonalnych, przeł. B. Kupis, Warszawa 1968.

52 Ten pleonazm ma podkreślać intensyfikację wymiaru cielesnego.
} 
samoposiadające się, w przeciwieństwie do przeszłości, kiedy ciała były własnością władcy politycznego (wodza, króla, despoty), duchowieństwa (jurysdykcja religijna nad ciałami wiernych przez kodeksy zakazów, ograniczeń, grzechów), pana (właściciela $\mathrm{w}$ wypadku niewolnictwa lub seniora w przypadku porządku feudalnego) lub pracodawcy (ta ostatnia kategoria wprowadza ograniczenia tezy o samoposiadaniu ${ }^{53}$ ), zawsze jednak kogoś, kto stał wyżej w hierarchii społecznej bądź był zwyczajnie silniejszy:

w środowisku wiejskim ciała dziewcząt wydają się bardziej dostępne niż w mieście [w XIX wieku - G.W.]. Tutaj pozwala się chłopcu bezwstydnie używać „górnej części worka”, czyli pieścić piersi. Dotykanie waginy i łechtaczki wydaje się mniej nieprzyzwoite niż głęboki pocałunek, co nie przestaje dziwić czytelnika XXI wieku ${ }^{54}$.

Samoposiadanie jest jednak pozorne i ograniczone, co zostało już zasygnalizowane w kontekście stosunków pracy, a co staje się coraz częstszym przedmiotem krytyki. Ograniczenia i pozorność wolności w wypadku ciała pornograficznego sprowadza się do jego uwarunkowania przez częstokroć nieuświadamiane czynniki strukturalne, mamiące statusem podmiotowym, podczas gdy w rzeczywistości uprzedmiotawiają w sieci zależności twórców i widzów, którzy konsumują ciała pornograficzne jak konsumuje się kotlet podczas niedzielnego obiadu. Sytuację tę opisuje w kontekście tezy o utowarowieniu emocji izraelska socjolożka Eve Illouz:

Triumf miłości i wolności seksualnej zbiegł się z inwazją logiki ekonomicznej na maszynerię ludzkiego pożądania. Jedna z głównych przemian więzi seksualnych w nowoczesności wiąże się ze ścisłym powiązaniem pożądania z ekonomią i z kwestią ceny i wartości [...]. Idzie mi o to, że seksualna rywalizacja przekształciła strukturę woli i pożądania i że pożądanie przyjęło cechy rynkowej wymiany: to znaczy, że stało się regulowane przez prawa popytu i podaży, niedoboru i nadmiaru ${ }^{55}$.

„Somatyzacja” pornografii przynosi jeszcze jedno zagrożenie, którym jest wyalienowanie z własnego ciała, które niemiecki filozof Karol Marks opisywał na przykładzie pracowników dziewiętnastowiecznych fabryk, choć jego konstatacje miały, odmienny od prezentowanego tu, charakter konkluzywny. Ciało pornograficzne jest w kontekście towarowo-ekonomicznym traktowane jako narzędzie tudzież urządzenie, którego zadaniem jest wyprodukowanie konkretnego produktu, w tym wypadku obrazu pornograficznego, który zostanie skonsumowany przez odbiorcę, widza, klienta. W kontekście stosunków pracy podporządkowane jest pracodawcy (twórcom, reżyserom, sponsorom, wytwórniom), który rości

53 Por. prace amerykańskiej socjolożki Arlie R. Hochschild: eadem, The Time Bind: When Work Becomes Home and Home Becomes Work, New York 2001; eadem, Zarządzanie emocjami. Komercjalizacja ludzkich uczuć, przeł. J. Konieczny, Warszawa 2009.

54 A. Corbin, op. cit., s. 172; por. także G. Vigarello, Historia gwałtu, przeł. A. Leyk, Warszawa 2010, passim.

55 E. Illouz, Why Love Hurts: A Sociological Explanation, Cambridge-Malden 2012, s. 58; cyt. za: M. Musiał, op. cit., s. 85-86. 
sobie prawo do dysponowania jego parametrami pracy (szybkością, liczbą wykonanych ruchów, ilością czasu poświęconą na zdjęcia) ${ }^{56}$.

Pornografia „somatyczna” „podgrzewa” również oczekiwania w stosunku do seksu oraz możliwości własnego ciała, aktywując nierealistyczne wyobrażenia odnośnie do ludzkiej seksualności oraz anatomii, o czym szerzej autor pisał w innym artykule ${ }^{57}$. W przestrzeni epistemicznej może to prowadzić „niewyedukowanego" odbiorcę/odbiorczynię $e^{58}$ do dysonansu poznawczego, który może wywołać uczucie nieadekwatności, a nawet frustrację, dysforię czy depresję. Po lekturze pornografii (szczególnie tej profesjonalnej) można odnieść wrażenie, że ciała kobiet i mężczyzn muszą być estetyczne (oczywiście w kontekście obowiązującego w danym czasie kanonu) i wysportowane, że wargi sromowe mniejsze (labia minora) są zawsze małe, różowe i tak jakby „przycięte”, penis ma natomiast zawsze minimum dwadzieścia centymetrów i jest obrzezany ${ }^{59}$, a wszystkie narządy płciowe (srom i penis z moszną) są skrupulatnie wydepilowane. Ponadto osiągnięcie orgazmu jest niezwykle proste i oczywiste, nawet w najbardziej ekwilibrystycznych pozycjach („orgazm na zawołanie”), a jęki i spazmatyczne konwulsje są normą zachowania wszystkich ludzi uprawiających seks. Problemem są także standardowe elementy pornograficznej narracji - wytrysk na twarz ( $f a$ cial), połykanie nasienia, „głębokie gardło”, seks analny, biseksualny (szczególnie „lesbijski”) czy grupowy, które są nie tyle nieznane, co nie znajdują powszechnej akceptacji $^{60}$.

„Somatyzacja” pornografii może być postrzegana również jako radykalny wyraz materializmu i hedonizmu jako determinantów współczesnej kultury. Ta ostatnia zaś jawi się jako zagadnienie problemowe, które można definiować jedynie w kategoriach sensualistycznych i antyintelektualnych. Aspekty te podejmowane są częstokroć przez krytyków kultury, rekrutowanych z przedstawicieli różnych dyscyplin naukowych oraz środowisk społecznych ${ }^{61}$. Tym samym wielokrotnie zostaje zanegowany "pierwotny” walor emancypacyjny pornografii, który należy waloryzować pozytywnie. Pornografia, jak każde inne zjawisko kulturowe i społeczne, nie ma jednowartościowych substancjalnych i apriorycznych cech. Podkreśla to na przykład brytyjski medioznawca Brian McNair, choć można mu zarzucić w kilku miejscach jednostronność opisów oraz ignorowanie problemów, jakie może tworzyć pornografia, w postaci cierpienia, zniewole-

56 Por. A.R. Hochschild, Zarządzanie emocjami, s. 7 n.

57 Por. G. Wiktorowski, Pornografia - Not a Love Story?, s. 185-223; idem, Pornografia - od medykalizacji..., s. 225-273.

58 Chodzi tu o kwestię edukacji seksualnej.

59 Przewaga pornografii amerykańskiej.

60 Por. 11 sposobów, na które mainstreamowa pornografia wprowadza kobiety w błąd odnośnie sek$s u$, http://codziennikfeministyczny.pl/11-sposobow-na-ktore-mainstreamowa-pornografia-wprowadza-kobiety-blad-odnosnie-seksu/ (dostęp: 5.01.2017).

61 Problem ten omawia m.in. M. Musiał, op. cit., passim. 
nia, uzależnienia czy brutalności ${ }^{62}$. McNair wskazuje, że pornografia stabilizuje intymne relacje międzyludzkie, stanowi alternatywę wobec zdrady, urozmaicenie życia seksualnego, redukuje stres i napięcie seksualne, dostarcza podniety i przyjemności odbiorcom, niekiedy jedynej, czy też może stanowić materiał edukacji seksualnej dla osób dorosłych ${ }^{63}$. Ukazuje również przemiany w stosunkach pomiędzy płciami, emancypacji kobiet, szczególnie kobiecej seksualności, inkluzji seksualności nieheteronormatywnych. Dodać można, że dzisiejsza pornografia przestała być $-\mathrm{w}$ przekonaniu piszącego te słowa - fallocentrycznym kultem penisa $\mathrm{w}$ rozumieniu feministycznej krytyki antypornograficznej. Oczywiście w wymiarze somatycznym w pornografii tego typu penis, ze względu na swoją fizjologię i związaną z tym widzialność, jest istotny i obecny, pełni jednak - wyrażając się bardziej literacko - rolę „batuty dyrygenta kierującego uwerturą wygrywaną jednakowoż przez cipkę" ${ }^{34}$. Używając w tym miejscu metafory lingwistycznej, można stwierdzić, że podobnie jak w danym języku zmienia się w czasie zasób leksykalny, to jednak reguły gramatyczne nim rządzące pozostają niezmienione (wolniej podlegają zmianie). Innymi słowy, „ocalenie” walorów emancypacyjnych i zabezpieczenie przed negatywnym wtórnym wpływem pornografii możliwe jest wtedy, gdy zmianie ulegną jedynie formy wyrazu (w pornografii poszerzenie spektrum aktywności seksualnych, w pornografii „somatycznej” zaś zwiększenie możliwości ciała nie poprzez kolejne etapy transgresji, lecz wiedzę opartą na świadomości jego funkcji i mechaniki działania), natomiast reguły nimi kierujące pozostaną niezmienne (ponowne włączenie wymiarów relacyjnych, psychoemocjonalnych, społecznych ludzkiej aktywności seksualnej).

Odczarowując i sekularyzując ludzkie ciało, współczesne procesy medykalizacyjne ukonstytuowały jego widzialność, nie pozostawiając żadnej jego części poza zasięgiem wzroku podmiotu obserwującego. Pornografia tę przemianę zinstytucjonalizowała w perwersji voyeryzmu, która od „odczarowania” prowadzi do „rozczarowania”, ulegając ponowoczesnej nudzie i determinizmowi transgresji. Te ostatnie w konsekwencji przynoszą stan, który niemiecki teoretyk kultury, filozof i socjolog Georg Simmel określił mianem zblazowania:

62 Por. ibidem, s. 122.

63 Por. B. McNair, Seks, demokratyzacja pożądania i media, czyli kultura obnażania, przeł. E. Klekot, Warszawa 2004, passim; M. Musiał, op. cit., s. 119-122.

64 Słowo „cipka” jest już „obrosłe” semantycznie - zarówno w refleksji nad pornografią, jak i refleksji feministycznej. Ma ono nie wywoływać poczucia wstydu czy zgorszenia. Ma również przełamywać sztucznie (czytaj: patriarchalnie) narzucane zabiegi stylistycznej i retorycznej eufeminacji, niejako „zasłaniającej” clou problemu. Użycie słowa „cipka” jest także próbą „odczarowania” kobiecego ciała, na którego określenie w języku polskim występują jedynie słowa z zakresu mianownictwa medyczno-anatomicznego lub wulgaryzmy. Z drugiej strony, zastosowanie w tym miejscu wyrazu „wagina” nie oddałoby ciężaru semantycznego słowa „cipka”, które w pornografii nie tylko nie jest wulgaryzmem, lecz także nie jest powodem do wstydu, wyparcia, zaprzeczenia czy ukrycia. 
Do zblazowania prowadzi nieznające miary nadużywanie uciech zmysłowych, gdyż nerwy tak długo pobudzane do najsilniejszych reakcji tracą w ogóle zdolność reagowania, lecz również bardziej niewinne, ale szybko się zmieniające doznania targające nerwy aż do ostatecznego wyczerpania sił, tak iż jedynym ratunkiem jest natychmiastowa zmiana otoczenia. Taka obojętność na nowe podniety to jest właśnie zblazowanie [...]. Istotą zblazowania jest obojętność na różnorodne bogactwo przedmiotów nie w tym sensie, że zblazowany nie przyjmuje do wiadomości ich istnienia, ale w tym, że znaczenie i wartość różnorodności, a co za tym idzie i samych przedmiotów, odczuwana jest jako nieistotna. Przedmioty ukazują się osobie zblazowanej jako podobnie bezbarwne i pozbawione blasku, tak iż żaden nie zasługuje, by go przekładać nad inne ${ }^{65}$.

Choć słowa te socjolog napisał na początku XX wieku (1908 rok), diagnozując sytuację mieszkańca wielkiego miasta oraz odwołując się do dziewiętnastowiecznej mechaniki „nerwów”66, opisał działanie mechanizmów, które możemy obserwować obecnie. Nadmiar zintensyfikowanego ciała pornograficznego poprzez nasycenie, „przesycenie” nim obrazu wywołuje zobojętnienie i apatię, które $\mathrm{w}$ tak zwanym realu rezonują nie tylko zaburzeniami modelu kobiecości/męskości, kobiecej/męskiej seksualności, oczekiwań wobec niej, lecz także, a może przede wszystkim, rozpadem relacji i możliwości tworzenia trwałego związku. „Ponowoczesna nuda" ${ }^{67}$ zarówno wyraża więc stan ducha człowieka ponowoczesnego, jak i staje się dla niego stylem życia, co diagnozował literaturoznawca i antropolog kultury Mariusz Czubaj ${ }^{68}$. Gdzie zaprowadzi kolejny poziom transgresji? Po latach osiemdziesiątych XX wieku, czyli dekadzie ekscytacji otwartością seksualną, pomimo konserwatywnego zwrotu na przykład w USA wraz $\mathrm{z}$ administracją Ronalda Reagana, upowszechnieniem i prywatyzacją pornografii, modą na aktywność fizyczną, operacje plastyczne i inne bodyfikacje, rozpoczął się okres, w którym zaczęły pojawiać się pytania i wątpliwości odnośnie do nowych wymiarów „niestabilności ciała” ${ }^{69}$. Czy po „somatyzacji” pornografii kolejnym etapem będzie jej cyborgizacja, która ukaże nieokiełznany seks bez ograniczeń pomiędzy ciałami w części bądź w pełni zmechanizowanymi? Czy transgresyjnie przekroczymy następne poziomy naruszające kolejne wymiary ludzkiej autotomii? ${ }^{70}$

65 G. Simmel, Socjologia, przeł. M. Łukasiewicz, Warszawa 1975, s. 519.

66 Szerzej por. m.in. G. Wiktorowski, Dietetyka Sylvestra Grahama jako przykład standardu medycyny oraz reform dietetycznych $w$ USA $w$ 1. połowie XIX wieku, [w:] Lek roślinny, t. 5. Rośliny jako podstawa racjonalnej diety oraz źródło leków, red. B. Płonka-Syroka, A. Syroka, Wrocław 2016, s. $109-128$.

67 Tu: jako nieumiejętność utrzymania stabilizacji, dłuższego zainteresowania czymś, przełamywana potrzebą bezustannego eksperymentowania, ciągłej zmiany.

68 Por. M. Czubaj, Brojlery w McNudzie. Co robimy, kiedy nic nie robimy, „Polityka” 2002, nr 24, s. $50-53$.

69 Por. M. Peplinski, Nie-ludzie w post-kinie? Filmowe cyborgi, „Ekrany. Film \& Media” 2016, nr 6 (34), s. 49; szerzej m.in. G. Gajewska, Arcy-nie-ludzkie. Przez science fiction do antropologii cyborgów, Poznań 2010. Za tę uwagę dziękuję dr hab. Grażynie Gajewskiej z Zakładu Kultury Współczesnej i Multimediów Uniwersytetu im. Adama Mickiewicza w Poznaniu.

${ }^{70}$ Por. m.in. M. Musiał, Intymność dziś i jutro. Od emancypacji i uprzedmiotowienia do lalek i robotów, „Tematy z Szewskiej” 1, 2015, nr 15, s. 25-41. 
Na te pytania nie sposób w tym miejscu odpowiedzieć, możemy jednakże uspokoić „strachy” człowieka współczesnego sugestią zwrotu ku intuicjom wyrażonym w i przez regułę Paracelsusa: „wszystko jest trucizną i nic nie jest trucizną, bo tylko dawka czyni truciznę". Odnalezienie balansu, równowagi jawi się jako zadanie oraz wyzwanie, które stają również przed czytającym/czytającą te słowa.

\section{Bibliografia}

11 sposobów, na które mainstreamowa pornografia wprowadza kobiety w błąd odnośnie seksu, przeł. K. Matysiak, http://codziennikfeministyczny.pl/11-sposobow-na-ktore-mainstreamowa-pornografia-wprowadza-kobiety-blad-odnosnie-seksu/.

Aggrawal A., Forensic and Medico-legal Aspects of Sexual Crimes and Unusual Sexual Practices, Boca Raton 2009.

Banaszak E., Florkowski R., Intymne, prywatne, publiczne. O częściach ciała, które należy zakrywać..., [w:] Moralne obrazy. Społeczne i socjologiczne (de)konstrukcje seksualności, red. E. Banaszak, P. Czajkowski, Wrocław 2008.

Banaszak E., Florkowski R., Krótki kurs pornografii w kulturze popularnej, [w:] Moralne obrazy. Społeczne i socjologiczne (de)konstrukcje seksualności, red. E. Banaszak, P. Czajkowski, Wrocław 2008.

Banaszak E., Florkowski R., Medykalizacja jako forma dyskursu o ciele, „Fizjoterapia” 2010, nr 3.

Bieńko M., O ponowoczesnych przygodach zdrowego i chorego ciała w perspektywie nauk społecznych, [w:] $W$ zdrowiu $i w$ chorobie... Z badań antropologii medycznej $i$ dyscyplin pokrewnych, red. D. Penkala-Gawęcka, I. Main, A. Witeska-Młynarczyk, Poznań 2012.

Böhme H., Fetyszyzm i kultura. Inna teoria nowoczesności, przeł. M. Falkowski, Warszawa 2012.

Brach-Czaina J., Ciało współczesne, „Res Publica Nowa” 2000, nr 11.

Bragge L., Girls on top, 2004, http://www.theage.com.au/articles/2004/06/15/-1087244912619.html.

Brown H.G., I'm Wild Again: Snippets of My Life and a Few Brazen Thoughts, New York 2000.

Conrad P., Medicalization and social control, „Annual Review of Sociology” 18, 1992, nr 1.

Conrad P., The Medicalization of Society: On the Transformation of Human Conditions into Treatable Disorders, Baltimore 2007.

Corbin A., Spotykanie się ciał, [w:] Historia ciała, t. 2. Od Rewolucji do I wojny światowej, red. A. Corbin, przeł. K. Belaid, T. Stróżyński, Gdańsk 2013.

Czubaj M., Brojlery w McNudzie. Co robimy, kiedy nic nie robimy, „Polityka” 2002, nr 24.

Fedorczuk A., Marczuk B., Pornografia pustoszy mózgi dzieci, rozmowa z prof. Zbigniewem Lwem-Starowiczem, „Wprost” 2015, nr 46 (1705).

Foucault M., Podmiot i władza, przeł. J. Zychowicz, „Lewą Nogą” 1998, nr 10.

Gajewska G., Arcy-nie-ludzkie. Przez science fiction do antropologii cyborgów, Poznań 2010.

Gélis J., Ciało, Kościót, sacrum, [w:] Historia ciała, t. 1. Od renesansu do oświecenia, red. G. Vigarello, przeł. T. Stróżyński, Gdańsk 2015.

Grant E., Średniowieczne podstawy nauki nowożytnej w kontekście religijnym, instytucjonalnym oraz intelektualnym, przeł. T. Szafrański, Warszawa [2005].

Historia ciała, t. 1. Od renesansu do oświecenia, red. G. Vigarello, przeł. T. Stróżyński, Gdańsk 2015.

Historia ciała, t. 2. Od Rewolucji do I wojny światowej, red. A. Corbin, przeł. K. Belaid, T. Stróżyński, Gdańsk 2013.

Hochschild A.R., The Time Bind: When Work Becomes Home and Home Becomes Work, New York 2001.

Hochschild A.R., Zarzadzanie emocjami. Komercjalizacja ludzkich uczuć, przeł. J. Konieczny, Warszawa 2009. 
Kobieta i małżeństwo. Społeczno-kulturowe aspekty seksualności. Wiek XIX i XX, red. A. Żarnowska, A. Szwarc, Warszawa 2004.

Kobieta i praca. Wiek XIX i XX, red. A. Żarnowska, A. Szwarc, Warszawa 2000.

Kobieta $i$ rewolucja obyczajowa. Społeczno-kulturowe aspekty seksualności. Wiek XIX i XX, red. A. Żarnowska, A. Szwarc, Warszawa 2005.

Krafft-Ebing R. von, Psychopathia Sexualis, with Especial Reference to Contrary Sexual Instinct: A Medico-Legal Study, przeł. Ch.G. Chaddock, Philadelphia-London 1893.

McNair B., Seks, demokratyzacja pożądania i media, czyli kultura obnażania, przeł. E. Klekot, Warszawa 2004.

Musiał M., Intymność dziś i jutro. Od emancypacji i uprzedmiotowienia do lalek i robotów, „Tematy z Szewskiej" 1, 2015, nr 15.

Musiał M., Intymność i jej współczesne przemiany. Studium z filozofii kultury, Kraków 2015.

Nauka i społeczeństwo w stulecie szczególnej teorii względności Alberta Einsteina (1905-2005), red. B. Płonka-Syroka, Warszawa-Wrocław 2006.

Nye R.A., The evolution of the concept of medicalization in the late twentieth century, „Journal of the History of the Behavioral Sciences" 39, 2003, nr 2.

Otto R., Świętość. Elementy irracjonalne w pojęciu bóstwa i ich stosunek do elementów racjonalnych, przeł. B. Kupis, Warszawa 1968.

Peplinski M., Nie-ludzie w post-kinie? Filmowe cyborgi, „Ekrany. Film \& Media” 6, 2016, nr 34.

Płonka-Syroka B., Medycyna w historii i kulturze. Studia z antropologii wiedzy, Wrocław 2013.

Płonka-Syroka B., Wiktorowski G., Kształtowanie się standardu antropologii medycyny klinicznej w niemieckim i anglosaskim piśmiennictwie naukowym. Zarys zagadnienia, [w:] Podstawy interdyscyplinarności w naukach o zdrowiu. Poznawcza tożsamość dyscyplin badających socjokulturowy wymiar zdrowia i choroby, red. M. Skrzypek, Lublin 2014.

Płonka-Syroka B. et al., Zjawisko antykoncepcji w perspektywie społecznej i historycznej, Wrocław 2012.

Proces modernizacji nauk przyrodniczych $w$ historii i historiografii nauki, red. B. Płonka-Syroka, Wrocław 2003.

Przełom nowożytny w nauce europejskiej i jego kontekst społeczno-kulturowy, red. B. Płonka-Syroka, Wrocław 2004.

Rozkosz w kulturze, red. Ł. Wróblewski, A. Giza, Kraków 2016.

Sieradzan J., Szaleństwo $w$ religiach świata. Szamanizm, religia starogrecka, judaizm, chrześcijaństwo, hinduizm, buddyzm, islam, Kraków 2007.

Simmel G., Socjologia, przeł. M. Łukasiewicz, Warszawa 1975.

Słońska Z., Misiuna M., Promocja zdrowia. Słownik podstawowych terminów, Warszawa 1993.

Vigarello G., Historia gwattu, przeł. A. Leyk, Warszawa 2010.

Vigarello G., Historia zdrowia i choroby. Praktyki sanitarne od średniowiecza do wspótczesności, przeł. M. Szymańska, Warszawa 2011.

Wiktorowski G., Dietetyka Sylvestra Grahama jako przykład standardu medycyny oraz reform dietetycznych w USA w 1. połowie XIX wieku, [w:] Lek roślinny, t. 5. Rośliny jako podstawa racjonalnej diety oraz źródło leków, red. B. Płonka-Syroka, A. Syroka, Wrocław 2016.

Wiktorowski G., Model rodziny i relacji małżeńskich w amerykańskim fundamentalizmie protestanckim, [w:] Problem kontroli urodzeń i antykoncepcji. Krytyczno-porównawcza analiza dyskursów, red. B. Płonka-Syroka, A. Szlagowska, Wrocław 2013.

Wiktorowski G., Pornografia - Not a Love Story? Meandry paradygmatycznych przeinaczeń: miłość, seks, ciało, gender, medykalizacja, [w:] Miłość niemożliwa, red. B. Płonka-Syroka, A. Szlagowska, Wrocław 2016.

Wiktorowski G., Pornografia - od medykalizacji do „nozologicznej” precyzji na przykładzie pornografii internetowej, [w:] Miłość niemożliwa, red. B. Płonka-Syroka, A. Szlagowska, Wrocław 2016. 
Wiktorowski G., Przezwyciężyć „świat”. Elementy transgresyjne $w$ amerykańskim protestantyzmie fundamentalistycznym, [w:] Perspektywy poznawcze w kulturze europejskiej. Studium porównawcze, red. B. Płonka-Syroka, E.I. Rudolf, Wrocław 2012.

Wiktorowski G., Sposoby mówienia o aborcji. Implikacje ideowe dyskursu naukowego i światopogladowego, [w:] Problemy zdrowia reprodukcyjnego kobiet, t. 1. Wstęp do badań, red. A. Szlagowska, Wrocław 2016.

Williams L., Hard Core. Władza, przyjemność i „szaleństwo widzialności”, przeł. J. Burzyńska, I. Hansz, M. Wojtyna, Gdańsk 2010.

\section{Materiały audiowizualne}

9 Songs, reż. M. Winterbottom, Wielka Brytania 2004.

Ai no corrida (Imperium zmystów), reż. N. Ôshima, Francja/Japonia 1976.

Behind the Green Door, reż. A. Mitchell, J. Mitchell, USA 1972.

Debbie Does Dallas, reż. J. Buckley, USA 1978.

Deep Throat (Głębokie gardło), reż. G. Damiano, USA 1972.

Deep Throat Part II, reż. J.W. Sarno, USA 1974.

Devil in Miss Jones (Diabet w pannie Jones), reż. G. Damiano, USA 1973.

Every Woman Has a Fantasy, reż. E. Brown, USA 1984.

Habitación en Roma (Noc w Rzymie), reż. J. Médem, Hiszpania 2010.

Histoire d'O (Historia O), reż. J. Jaeckin, Francja/Włochy/RFN 1975.

Intimacy (Intymność), reż. P. Chéreau, Francja/Hiszpania/Niemcy/Wielka Brytania 2001.

La vie d'Adèle (Życie Adeli - Rozdział 1 i 2), reż. A. Kechiche, Belgia/Francja/Hiszpania/Tunezja 2013.

Nymphomaniac (Nimfomanka), reż. L. von Trier, Belgia/Dania/Francja/Niemcy/Wielka Brytania 2013.

Shortbus, reż. J.C. Mitchell, USA 2006.

Three Daughters, reż. C. Royalle, USA 1986.

\section{"Frenzy of bodies" — contemporary pornography and body medicalization. Historical-medical implications}

\section{Summary}

The author believes that pornography of last few decades has gone changes which have not occurred since ancient times. These changes were initiated especially by the processes of medicalization and, therefore, rationalization of the human body. Stripped from the odium of the sacrum (sacred things), the mystery or the cosmological battle between Good and Evil, the body has been subjected to instrumentalisation in different dimensions. The last stage of changes that can be observed in contemporary pornography is its "somatization". It is defined by the author as a functional and qualitative "reorientation" which means that pornographic narration is deprived of presenting emotional, relational or moral elements and aspects. The narration does not focus just on the "technology" of the sexual act, but merely concentrates on the body, even going deep inside. 